\title{
A novel thermostable nitrilase superfamily amidase from Geobacillus pallidus showing acyl transfer activity
}

\author{
H. S. Makhongela • A. E. Glowacka • V. B. Agarkar • \\ B. T. Sewell • B. Weber • R. A. Cameron • D. A. Cowan • \\ S. G. Burton
}

Received: 19 November 2006 / Revised: 8 February 2007 / Accepted: 8 February 2007 / Published online: 9 March 2007

(C) Springer-Verlag 2007

\begin{abstract}
An amidase (EC 3.5.1.4) in branch 2 of the nitrilase superfamily, from the thermophilic strain Geobacillus pallidus RAPc8, was produced at high expression levels $(20 \mathrm{U} / \mathrm{mg})$ in small-scale fermentations of Escherichia coli. The enzyme was purified to $90 \%$ homogeneity with specific activity of $1,800 \mathrm{U} / \mathrm{mg}$ in just two steps, namely, heat-treatment and gel permeation chromatography. Sodium dodecyl sulfate-polyacrylamide gel electrophoresis (SDS-PAGE) and electron microscopic (EM) analysis of the homogenous enzyme showed the native enzyme to be a homohexamer of $38 \mathrm{kDa}$ subunits. Analysis of the biochemical properties of the amidase showed that the optimal temperature and $\mathrm{pH}$ for activity were 50 and $7.0^{\circ} \mathrm{C}$, respectively. The amidase exhibited high thermal stability at 50 and $60^{\circ} \mathrm{C}$, with half-lives greater than $5 \mathrm{~h}$ at both temperatures. At 70 and $80^{\circ} \mathrm{C}$, the half-life values were 43 and $10 \mathrm{~min}$, respectively. The amidase catalyzed the
\end{abstract}

H. S. Makhongela $\cdot$ A. E. Glowacka $\cdot$ S. G. Burton $(\bowtie)$

Bioprocess Engineering Research Unit,

Department of Chemical Engineering,

University of Cape Town,

Rondebosch,

Cape Town, South Africa

e-mail: Stephanie.Burton@uct.ac.za

V. B. Agarkar • R. A. Cameron • D. A. Cowan

Advanced Research Centre for Applied Microbiology,

Department of Biotechnology,

University of the Western Cape,

Bellville,

Cape Town, South Africa

B. T. Sewell • B. Weber

Electron Microscope Unit,

University of Cape Town,

Rondebosch,

Cape Town, South Africa hydrolysis of low molecular weight aliphatic amides, with D-selectivity towards lactamide. Inhibition studies showed activation/inhibition data consistent with the presence of a catalytically active thiol group. Acyl transfer reactions were demonstrated with acetamide, propionamide, isobutyramide, and acrylamide as substrates and hydroxylamine as the acyl acceptor; the highest reaction rate being with isobutyramide. Immobilization by entrapment in polyacrylamide gels, covalent binding on Eupergit $\mathrm{C}$ beads at $4^{\circ} \mathrm{C}$ and on Amberlite-XAD57 resulted in low protein binding and low activity, but immobilization on Eupergit $\mathrm{C}$ beads at $25^{\circ} \mathrm{C}$ with cross-linking resulted in high protein binding yield and high immobilized specific activity $(80 \%$ of non-immobilized activity). Characterization of Eupergit C-immobilized preparations showed that the optimum reaction temperature was unchanged, the $\mathrm{pH}$ range was somewhat broadened, and stability was enhanced giving half-lives of $52 \mathrm{~min}$ at $70^{\circ} \mathrm{C}$ and $30 \mathrm{~min}$ at $80^{\circ} \mathrm{C}$. The amidase has potential for application under high temperature conditions as a biocatalyst for D-selective amide hydrolysis producing enantiomerically pure carboxylic acids and for production of novel amides by acyl transfer.

Keywords Amidase Enantioselectivity

Substrate specificity Thermostable Characterization . Immobilization

\section{Introduction}

Hydrolysis of carbon-nitrogen linkages in biological systems may be catalyzed by enzymes from a wide range of classes and among these, amidases catalyze the hydrolysis of carboxylic acid amides to free carboxylic acids and ammonia. 
A number of studies of amidase classification (Chebrou et al. 1996; Fournand and Arnaud 2001) have shown that amidases fall into two categories. The first group, those belonging to the nitrilase superfamily, includes aliphatic amidases, which hydrolyze only short-chain aliphatic amides. These enzymes are typically homohexamers of approximately $230 \mathrm{kDa}$, each subunit containing a cysteine residue which is believed to act as the catalytic nucleophile. These enzymes are also known as the wide spectrum amidases and do not contain the central conserved GGSSsignature in their amino acid sequence which is common to all other amidase enzymes. Members of the nitrilase superfamily are classified into 13 branches, in which the substrate specificity of members of nine of these branches is well-known (Pace and Brenner 2001). Of the members of these nine branches whose substrate specificity is well documented (nitriles, acid amides, secondary amides and $\mathrm{N}$ carbamyl amides), only one branch is known to have nitrilase activity, whereas eight branches have apparent amidase or amide-condensation activities (Pace and Brenner 2001). Amidases hydrolyzing small molecular weight aliphatic amides, such as that from Geobacillus pallidus RAPc8 (the subject of the present study), belong to Branch 2 of the nitrilase superfamily, in the classification of Pace and Brenner (2001).

The site-directed mutagenesis of an invariant cysteine residue in the Pseudomonas aeruginosa amidase revealed that Cys166 acted as the nucleophile in the catalytic mechanism (Farnaud et al. 1999). The crystal structures of nitrilase superfamily members (PDB: $1 \mathrm{ems}$ ), worm NitFit (Pace and Brenner 2001), and bacterial (PDB: 1erz) Ncarbamyl-D-amino acid amidohydrolase (Nakai et al. 2000) indicate that these enzymes were multimeric $\alpha-\beta-\beta-\alpha$ sandwich fold proteins and have a conserved Glu, Lys, Cys catalytic triad responsible for covalent catalysis (Pace et al. 2000; Brenner 2002).

Despite the fact that most branches of the nitrilase superfamily are actually amidases, there are many amidases (triad hydrolases, amidase signature enzymes, and thiol proteases) that are not related to the nitrilase superfamily. This second group includes aliphatic amidases which hydrolyze mid-length amides, some arylamides, $\alpha$-aminoamides, and $\alpha$-hydroxyamides. These enzymes often demonstrate enantioselectivity, and they belong to the group of the GGSS signature-containing amidase family (Chebrou et al. 1996). Kobayashi et al. (1997) have reported that these enzymes contain asparagine and serine residues in their active site. With the exception of Bacillus sp. BR449 amidase, and the G. pallidus RAPc8 amidase reported in this study, all nitrile hydratase-coupled amidases belong to the signature amidase class and are typically homodimers with a native molecular weight of approximately $110 \mathrm{kDa}$ (Cameron et al. 2005).
Amidases have been found in many members of the bacterial kingdom, and the substrate specificities and biological functions of these enzymes vary widely, but they are typically involved in carbon/nitrogen metabolism in prokaryotes (Banerjee et al. 2002). Many amidases are stereoselective, and some hydrolyze amides of $\alpha$ - or $\beta$ amino acids (Kotlova et al. 1999). Amidases are among the most widely used amide-hydrolyzing enzymes in industry, in both their free or immobilized forms. Several organic compounds, including $p$-aminobenzoic acid, acrylic acid, nicotinic acid, pyrazinoic acid, and 3-indole acetic acid, are commercially produced through the biotransformation of nitriles using nitrile hydratases and amidase activities (Banerjee et al. 2002). Amidases also find application as industrial catalysts in the treatment of industrial effluents containing toxic amides, in organic synthesis, and as therapeutic agents (Madhavan et al. 2005).

A thermostable amidase was previously identified in a thermophilic G. pallidus (Periera et al. 1998). The open reading frame (ORF) encoded a 348-amino acid amidase (MW $38.6 \mathrm{kDa}$ ), located immediately downstream of ORFs encoding nitrile hydratase $\alpha$ and $\beta$ subunits, was cloned and over-expressed in E. coli BL21 (DE3) (Cameron et al. 2005). Here, we report studies of the biochemical properties of the G. pallidus RAPc8 amidase, including substrate specificity, chiral selectivity, and enzyme kinetic parameters together with operating parameters (i.e., temperature, $\mathrm{pH}$, and thermostability) for the free and immobilized biocatalyst.

\section{Materials and methods}

\section{Materials}

All chemicals were purchased from Sigma-Aldrich (SA), except for D- and L-lactamide, which were from SigmaAldrich (International). All solvents were purchased from Merck-SA. Eupergit CM was a gift from Röhm Pharma Polymers (Darmstadt, Germany). The reactor, constructed from borosilicate 3.3-type glass, was purchased from Glasschem, Stellenbosch (South Africa). The E. coli strain BL 21 (DE3) (Stratagene) harboring plasmid pNH223 encoding the $G$. pallidus RAPc8 amidase gene was provided by Cameron et al. (2005).

Fermentation

A New Brunswick Scientific BIOFLO 110 series fermentation unit, fitted with online $\mathrm{pH}$, dissolved oxygen, and temperature controls, was used for all fermentations. A 500-ml volume of a $15-\mathrm{h}$ E. coli $\mathrm{pNH} 223$ culture was used to inoculate approximately 4.51 of nutrient broth media 
supplemented with $4.5 \mathrm{ml}$ of $50 \mathrm{mg} / \mathrm{ml}$ carbenicillin solution. Fermentation conditions were: $37^{\circ} \mathrm{C}, 3 \mathrm{vvm}$ aeration, $500 \mathrm{rpm}$ agitation, and an initial $\mathrm{pH}$ of 6.8 . Samples, $20 \mathrm{ml}$, were withdrawn every $30 \mathrm{~min}$ for analysis of absorbance $\left(A_{600}\right)$ and amidase activity. Amidase expression was induced by addition of isopropyl $\beta$-D-1thiogalactopyranoside (IPTG) to a final concentration of $0.4 \mathrm{mM}$ when the optical density was approximately 0.60 .

Extraction, purification, and molecular weight determination of $G$. pallidus RAPc8 amidase

Cells were harvested by centrifugation at $8,000 \mathrm{rpm}$ for $15 \mathrm{~min}$ at $4{ }^{\circ} \mathrm{C}$ and resuspended in an appropriate amount of $50 \mathrm{mM}$ potassium phosphate buffer ( $\mathrm{pH}$ 7.0). Cell lysis was achieved by freezing the cells at $-20^{\circ} \mathrm{C}$ overnight, thawing at room temperature and sonication for 6-10 cycles of 2 min bursts followed by $30 \mathrm{~s}$ breaks. After centrifugation $(12,000 \mathrm{rpm}, 10 \mathrm{~min})$, the soluble fraction was heat-treated $\left(65^{\circ} \mathrm{C}, 45 \mathrm{~min}\right)$. Precipitated proteins were removed by centrifugation $(12,000 \mathrm{rpm}, 45 \mathrm{~min})$ and the resulting semipurified amidase solution stored at $-20^{\circ} \mathrm{C}$ until further use. Further purification was performed by S-300 HR gel exclusion chromatography column (GE-Healthcare) preequilibrated with buffer containing $150 \mathrm{mM} \mathrm{NaCl}$ and $50 \mathrm{mM}$ potassium phosphate buffer ( $\mathrm{pH}$ 7.0). Before electron microscopy, the enzyme was purified to homogeneity as follows: the sample was applied to a Sephacryl S300 HR column (GE-Healthcare) and eluted with $20 \mathrm{mM}$ Tris, $150 \mathrm{mM} \mathrm{NaCl}, 1 \mathrm{mM}$ dithiothreitol (DTT) ( $\mathrm{pH} 7.4$ ) over a total volume of $120 \mathrm{ml}$. Fractions were collected at 3-min intervals with a Gilson FC 203B fraction collector at a flow rate of $0.5 \mathrm{ml} / \mathrm{min}$. Amidase homogeneity and subunit molecular mass were determined at all stages by sodium dodecyl sulfate-polyacrylamide gel electrophoresis (SDS-PAGE) and non-denaturing gel electrophoresis (native-PAGE) using 12\% gels stained with Coomassie blue R-250 (Laemmli 1970). Samples were assayed for protein concentration using the Bradford protein determination kit (BioRad) with bovine serum albumin as standard.

Electron microscopy and image analysis

Purified amidase $(3 \mu \mathrm{l})$ at a concentration of $0.05 \mathrm{mg} / \mathrm{ml}$ was applied to carbon films which had been glow discharged for $30 \mathrm{~s}$, rinsed on two droplets of water, blotted, and negatively stained with $2 \%$ uranyl actate. Images were recorded at minimum dose (approximately $100 \mathrm{el} / \mathrm{A} 2$ ) using a Zeiss 912 electron microscope set for zero energy loss imaging at $120 \mathrm{kV}$ and $\times 50,000$ magnification on a Proscan $2 \mathrm{k} \times 2 \mathrm{k}$ CCD camera. The magnification on the CCD had previously been determined to be $2.28 \AA$ per pixel under these conditions. Images $(12,698)$ of the putative amidase were manually selected using Ximdisp (Crowther et al. 1996). The images were aligned to the image average and subjected to principal component analysis as in Frank (2006) using the SPIDER package (Frank et al. 1996). Images corresponding to the three symmetric views were isolated by reference-based alignment and averaged.

Immobilization of G. pallidus RAPc8 amidase

A volume of $5 \mathrm{ml}$ of the $90 \%$ purified enzyme $(2 \mathrm{mg} / \mathrm{ml}$ protein) was added to $1 \mathrm{~g}$ dry Eupergit $\mathrm{C}$ beads and the mixture incubated at either room temperature $\left(\sim 25^{\circ} \mathrm{C}\right)$ or $4^{\circ} \mathrm{C}$ for $72 \mathrm{~h}$. The beads were recovered by filtration and then washed three times with $15 \mathrm{ml}$ of $50 \mathrm{mM}$ potassium phosphate buffer, $\mathrm{pH}$ 7.0. Filtrates, supernatants, and wash fractions were collected separately for subsequent assays. A method adapted from Torres-Bacete et al. (2000) was used to co-immobilize the amidase with bovine serum albumin. Glutaraldehyde and 1-ethyl-3-[3-dimethylaminopropyl]carbodiimide hydrochloride (EDAC) were used for cross-linking of the amidase at concentrations between $2 \%(\mathrm{w} / \mathrm{v})$ and $0.5 \%(\mathrm{w} / \mathrm{v})$ according to the methods of Torres-Bacete et al. (2001). The methods used for entrapment of amidase in polyacrylamide gels and covalent binding to Amberlite-XAD57 beads were adapted from Toogood et al. (2002).

\section{Amidase activity assay}

Amidase activity was determined by the release of ammonia from the hydrolysis of amides using the phenol-hypochlorite ammonia detection method (Weatherburn 1967). Unless otherwise specified, all amidase-catalyzed reactions were performed as follows: aliquots of the reaction mixture $(300 \mu \mathrm{l})$ containing $25 \mathrm{mM}$ substrate, $10 \mu \mathrm{l}$ partially or fully purified $(0.5 \mathrm{mg} / \mathrm{ml})$ amidase or immobilized amidase ( $i$-amidase) and $50 \mathrm{mM}$ potassium phosphate buffer $\mathrm{pH} 7.2$ were added to $350 \mu$ reagent $\mathrm{A}(0.59 \mathrm{M}$ phenol and $1 \mathrm{mM}$ sodium nitroprusside), followed by the addition of $350 \mu \mathrm{l}$ reagent $\mathrm{B}(2.0 \mathrm{M}$ sodium hydroxide and $0.11 \mathrm{M}$ sodium hypochlorite). Activity was measured spectrophotometically at $600 \mathrm{~nm}$ after $15 \mathrm{~min}$ incubation at room temperature. Standards were prepared using ammonium chloride. Immobilized amidase preparations were assayed essentially as described above, except that $200 \mathrm{mg}$ of immobilized biocatalyst was used in each reaction mixture and the reaction mixture was subject to gentle shaking during the assay period. One unit of enzyme activity was described as the amount of enzyme that catalyzed the release of $1 \mu \mathrm{mol}$ of $\mathrm{NH}_{3}$ per minute under standard assay conditions. Control reactions were conducted in the absence of amidase. 
Acyl transfer activity assay

Acyl transfer reactions were performed using a modified version of the method of Fournand et al. (1998). A standard reaction mixture $(0.475 \mathrm{ml})$ contained amide substrate (acetamide, $95 \mathrm{mM}$ ) and hydroxylamine (freshly prepared $0.5 \mathrm{mM})$ in $50 \mathrm{mM}$ potassium phosphate buffer $(\mathrm{pH} 7.0)$. The reaction mixture was then preincubated $2 \mathrm{~min}$ at $50^{\circ} \mathrm{C}$. The reaction was started by addition of $0.025 \mathrm{ml}$ of thermostable amidase and was terminated after $2.5 \mathrm{~min}$. Every sample was mixed with $1 \mathrm{ml}$ of acidic solution of $\mathrm{FeCl}_{3}(0.133 \mathrm{M}$ in $\mathrm{HCl} 0.68 \mathrm{M})$. The amount of acethydroxamic acid was determined spectrophotometrically at $\lambda 500 \mathrm{~nm}$ using $\varepsilon=996 \mathrm{M}^{-1} \mathrm{~cm}^{-1}$. All reactions were performed in Eppendorf tubes at $50^{\circ} \mathrm{C}$. Control reactions were carried out in the absence of enzyme. For other substrates, the mean $\varepsilon_{M}$ value of the iron (III)/ligand complexes at $500 \mathrm{~nm}, 1,016 \mathrm{M}^{-1} \mathrm{~cm}^{-1}$, was used according to the method of Fournand et al. (1997).

Kinetic parameters for the reaction of hydroxamic acid formation catalyzed by the $G$. pallidus amidase were determined for acetamide concentrations of 5 to $300 \mathrm{mM}$ and acylamide concentrations of 5 to $120 \mathrm{mM}$. The kinetic constants $K_{\mathrm{m}}$, and $V_{\max }$ were estimated by the Hanes linearization method (plotting substrate concentration/initial reaction velocity vs substrate concentration) and $k_{\text {cat }}$ was calculated using a molecular mass of the amidase of $38.6 \mathrm{kDa}$. One unit of activity denotes $1 \mu \mathrm{mol}$ hydroxamic acid or ammonia formed per minute under conditions of $\mathrm{pH} 7$ and $50^{\circ} \mathrm{C}$. Specific activity of amidase was expressed in $\mathrm{U}$ per $\mathrm{mg}$ protein.

\section{Determination of optimal reaction temperature}

Reactions were carried out at temperatures between 30 and $80^{\circ} \mathrm{C}$ in $1.8 \mathrm{ml}$ Eppendorf tubes. For partially purified amidase extract $(0.5 \mathrm{mg} / \mathrm{ml}), 10 \mu \mathrm{l}$ was added to $300 \mu \mathrm{l}$ of

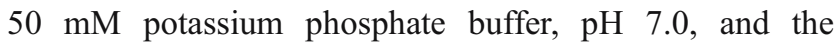
mixture pre-incubated for $1 \mathrm{~min}$ at the desired temperature Acetamide (substrate) was then added to a final concentration of $25 \mathrm{mM}$, and the reaction mixture was further incubated for $1 \mathrm{~min}$. Control reactions were carried out with the absence of the enzyme.

\section{Determination of optimal $\mathrm{pH}$}

Sodium acetate, $50 \mathrm{mM}$, potassium phosphate and Tris$\mathrm{HCl}$ buffers were used for $\mathrm{pH}$ values of 4-5, 6-8, and 9-10, respectively. Volumes $(10 \mu \mathrm{l})$ of semi-purified amidase $(0.5 \mathrm{mg} / \mathrm{ml})$ were added to $300 \mu \mathrm{l}$ volumes of $50 \mathrm{mM}$ buffer. The mixture was pre-incubated at $50^{\circ} \mathrm{C}$ for $1 \mathrm{~min}$. Acetamide ( $25 \mathrm{mM}$ final concentration) was added, and the reaction mixture was incubated for a further $1 \mathrm{~min}$ at $50^{\circ} \mathrm{C}$.
Thermal stability

The thermal stabilities of the free and immobilized amidase were determined at temperatures between 50 and $80^{\circ} \mathrm{C}$. Aliquots of purified amidase and immobilized amidase were incubated in a water bath for $3 \mathrm{~h}$ at specified temperatures. For the free enzyme, $10 \mu \mathrm{l}$ samples were withdrawn at 10 - or 15-min intervals initially (when reaction rates were high) and then 30-min intervals and assays for residual activity were performed as described above. For the immobilized enzyme, the solutions were decanted, and the activity of the biocatalyst was measured as described above.

\section{Substrate specificity}

Stocks of $1 \mathrm{M}$ amides were prepared in deionized water, except for L-alaninamide hydrochloride (prepared in 29\% (w/v) $\mathrm{NaOH}$ ), D,L-phenylalaninamide (prepared in $1 \mathrm{M}$ $\mathrm{NaOH})$ and hexanoamide (prepared in 50\% $(v / v)$ ethanol). All reactions were carried out in glass reaction tubes at $50^{\circ} \mathrm{C}$. Of purified amidase, $100 \mu \mathrm{l}$ was added to $3.0 \mathrm{ml}$

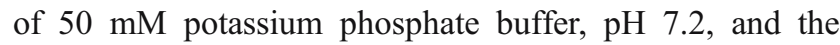
mixture pre-incubated for $5 \mathrm{~min}$. Substrate was added to a final concentration of $10 \mathrm{mM}$ and the reaction mixture incubated for a further $60 \mathrm{~min}$. Samples were withdrawn at intervals and assayed for amidase activity as described above.

\section{Amidase inhibition}

Stocks of metal salts, $100 \mathrm{mM}$, sulfhydryl reagents, and chelating agents were prepared in deionized water. A 100-mM stock of phenylmethylsulphonyl fluoride (PMSF) was prepared in anhydrous ethanol. All reactions were carried out as described above. Control reactions, lacking either the enzyme or the additive, were performed in parallel.

\section{Results}

Purification and subunit molecular weight determination of the recombinant $G$. pallidus RAPc8 amidase

After induction of $E$. coli pNH223 cultures with IPTG, amidase specific activity increased to a maximum of approximately $18 \mathrm{U} / \mathrm{mg}$ at a culture absorbance of 1.5 . Recovery of the amidase by sonication and centrifugation resulted in a soluble crude extract containing $426 \mathrm{mg} / \mathrm{ml}$ protein. A single $65^{\circ} \mathrm{C}$ heat-treatment step resulted in precipitation of approximately $50 \%$ of total protein, a $200 \%$ increase in total activity in solution, and a fourfold increase in specific activity (Table 1). Analysis of the heat- 
Table 1 Purification table for recombinant G. pallidus RAPc8 amidase

\begin{tabular}{llllll}
\hline $\begin{array}{l}\text { Purification } \\
\text { step }\end{array}$ & $\begin{array}{l}\text { Total } \\
\text { protein }(\mathrm{mg})\end{array}$ & $\begin{array}{l}\text { Total } \\
\text { activity }(\mathrm{U})\end{array}$ & $\begin{array}{l}\text { Specific } \\
\text { activity (U/mg) }\end{array}$ & $\begin{array}{l}\text { Purification } \\
\text { (fold) }\end{array}$ & $\begin{array}{l}\text { Yield } \\
(\%)\end{array}$ \\
\hline Crude extract & 426 & 15,980 & 37.5 & 1 & 100 \\
Heat-treatment & 209 & 30,930 & 148.0 & 4 & 194 \\
Gel permeation chromatography & 178 & 39,534 & 221.0 & 6 & 247 \\
\hline
\end{tabular}

purified enzyme by SDS-PAGE (Fig. 1) indicated that this preparation was approximately $90 \%$ homogeneous. The putative amidase band gave an approximate subunit molecular weight of $38 \mathrm{kDa}$, a value consistent with that derived from the translated gene sequence $(38.6 \mathrm{kDa}$; Cameron et al. 2005). The mobility of the active enzyme on native acrylamide gel electrophoresis (data not shown) was consistent with the presence of a homohexameric native structure. Gel filtration analysis on the preparative column resulted in a peak near the void volume of the column and a peak with an apparent molecular weight of $218 \mathrm{kDa}$.

Electron microscopy of the homogenously purified protein (Fig. 2) showed that the high molecular weight peak seen on the preparative column comprised mainly of aggregated particles, each having a size of $10 \mathrm{~nm}$, arranged

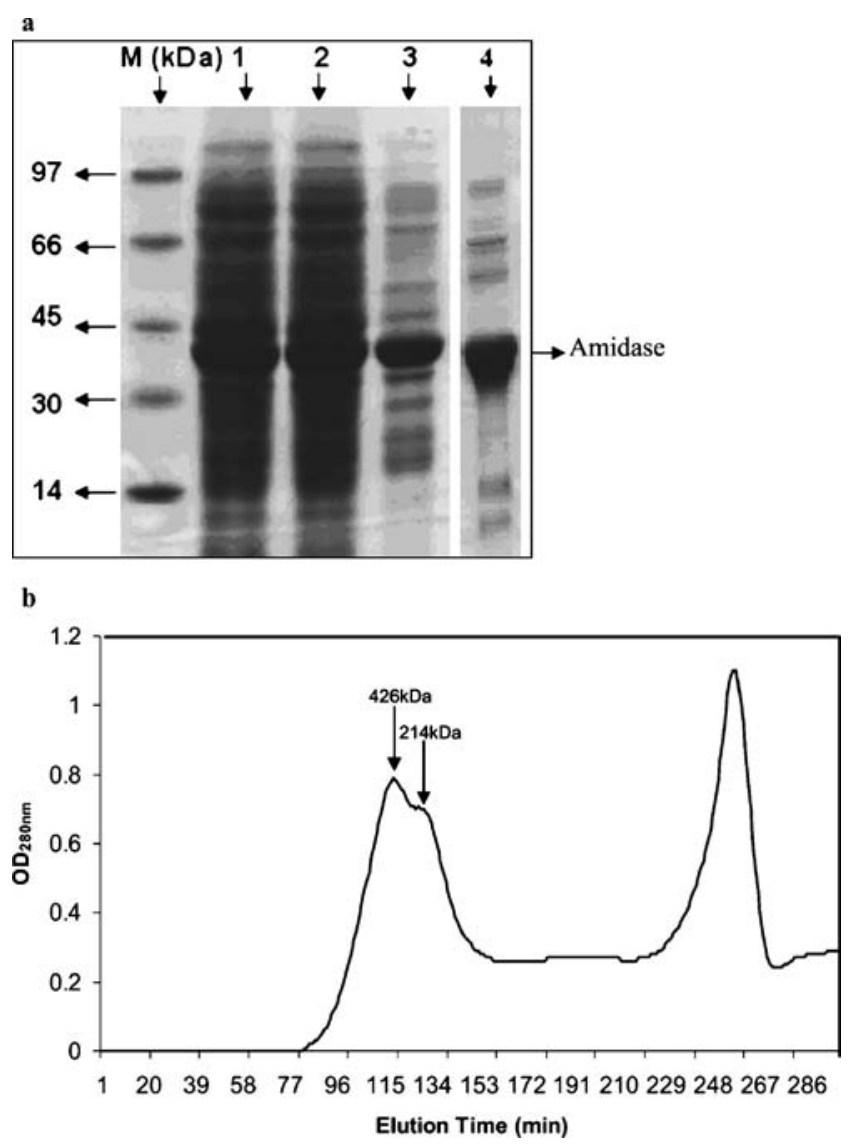

Fig. 1 a SDS-PAGE gel electrophoresis: lane $M$ : molecular weight markers, 1 induced cells, 2 clarified cell extract, 3 heat-treated extract, 4 pooled fractions from gel exclusion chromatography (a); gel filtration of purified G. pallidus RAPc8 amidase (b) in rows, whereas the $218-\mathrm{kDa}$ peak contained mainly disperse $10 \mathrm{~nm}$ particles. A large number of the particles had an approximately square profile. Particles with distinct triangular appearances, although relatively uncommon, were also easy to identify. Principal component analysis (Bretaudiere and Frank 1986) of 12,698 aligned particle images gave rise to eigenimages with clear two-, three-, and sixfold symmetry (among a variety of other shapes). These eigenimages were interpreted as being evidence that the particle had D3 point group symmetry, as the alternative C3 point group symmetry would only be expected to give rise to the threefold eigenimage. It was therefore concluded that the roughly square images, of which twofold eigenimage is a component, were projections at right angles to those having a triangular projection.

Amidase immobilization

Protein binding and activity yield results obtained from immobilization of the heat treatment-purified amidase using different immobilization techniques are shown in Table 2. Immobilization by covalent binding to Eupergit $C$, both at 4 and $25^{\circ} \mathrm{C}$ and adsorption on activated Amberlite-XAD57 gave low protein binding yields. Significantly higher protein binding yields were obtained by covalent immobilization on Eupergit $\mathrm{C}$ with BSA and on Eupergit $\mathrm{C}$ beads after cross-linking with glutaraldehyde and EDAC. Higher concentrations of the cross-linking agents substantially improved the immobilization efficiency. Low activity preparations were obtained after immobilization by covalent binding on Eupergit $\mathrm{C}$ beads $\left(4^{\circ} \mathrm{C}\right)$, entrapment in polyacrylamide gels, adsorption on Amberlite-XAD57 beads, and covalent binding on Eupergit $\mathrm{C}$ beads crosslinked with 1.0 and $2.0 \%(w / v)$ glutaraldehyde and EDAC (Table 2). Immobilization by covalent binding on Eupergit $\mathrm{C}$ beads at $25^{\circ} \mathrm{C}$, coupling with $\mathrm{BSA}$, and cross-linking with low concentrations $(0.5 \%(w / v)$ of glutaraldehyde and EDAC all resulted in high immobilized amidase activities.

Determination of temperature and $\mathrm{pH}$ optima

The activities of the free and immobilized amidase were investigated across a range of reaction temperatures. The temperature response of the free amidase showed a maximum activity at $50^{\circ} \mathrm{C}$, for a $1-\mathrm{min}$ reaction period, 
a
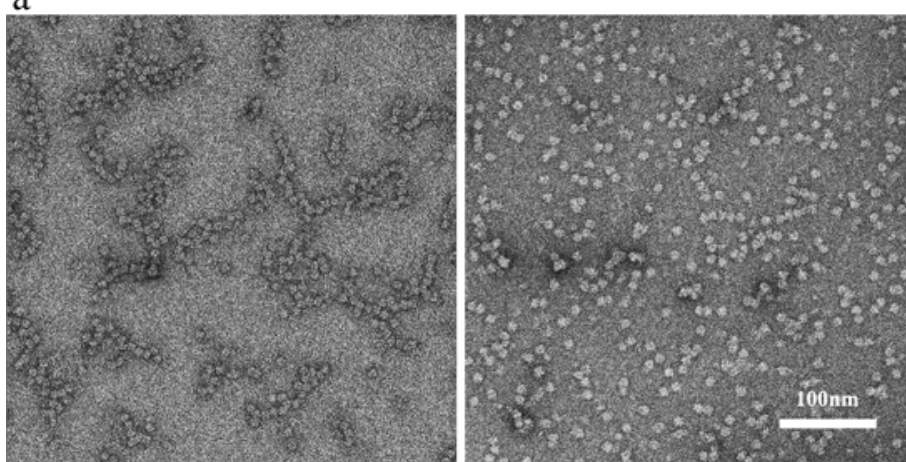

Fig. 2 Electron microscopic visualization of purified native $G$. pallidus RAPc8 amidase. The fractions at the void volume of the column (a) show aggregates of homogeneous particles of approxi- b

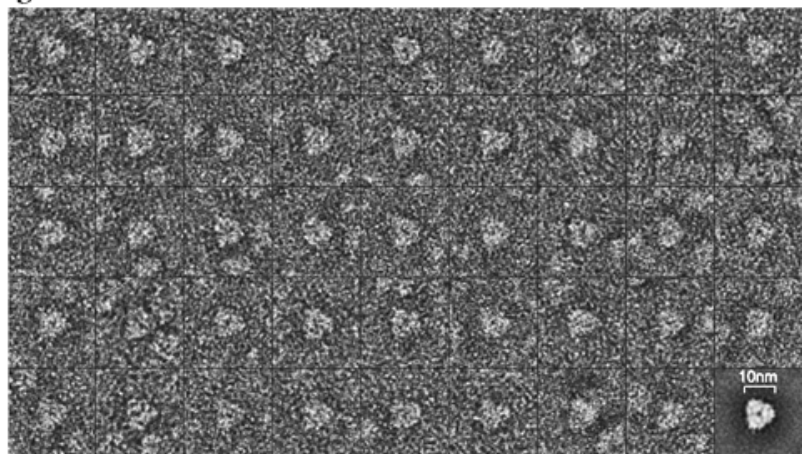

mately $10 \mathrm{~nm}$ in dimension, whereas those near the 218-kDa peak (b) are predominantly monodisperse. Particles with a triangular shape show clear threefold symmetry after being aligned and averaged (c)

Thermal stability

but with a very broad temperature-activity peak and little apparent loss of activity up to approximately $70^{\circ} \mathrm{C}$ (Fig. 3a). Analysis of the immobilized preparation (Fig. 3b) showed no significant increase in the temperature optimum for activity.

Using a range of buffers over a $\mathrm{pH}$ range from 5 to 10 and two different amide substrates (acetamide and acrylamide), the specific activity of free amidase was found to be maximal at $\mathrm{pH} 7.0$ (Fig. 4a). Both substrates showed essentially identical $\mathrm{pH}$-activity profiles (data not shown). A determination of the $\mathrm{pH}$-activity characteristics of the Eupergit C-immobilized amidase preparation (Fig. 4b) showed a substantial broadening of the $\mathrm{pH}$-activity peak in the alkaline $\mathrm{pH}$ region, in comparison to the free enzyme.

Table 2 Binding and activity yields for immobilized amidase preparations

\begin{tabular}{|c|c|c|}
\hline Immobilization method & $\begin{array}{l}\text { Protein binding } \\
\text { yield }^{\mathrm{a}}(\%)\end{array}$ & $\begin{array}{l}\text { Activity } \\
\text { yield }^{\text {b }(\%)}\end{array}$ \\
\hline Eupergit $\mathrm{C}, 4^{\circ} \mathrm{C}$ & 13.3 & 28 \\
\hline Eupergit $\mathrm{C}, 25^{\circ} \mathrm{C}$ & 35.4 & 94 \\
\hline Polyacrylamide gel, $25^{\circ} \mathrm{C}$ & - & 2 \\
\hline $\begin{array}{l}\text { Eupergit C (BSA coupled), } \\
25^{\circ} \mathrm{C}\end{array}$ & 56.6 & 81 \\
\hline $\begin{array}{l}\text { Eupergit C }(2.0 \mathrm{w} / \mathrm{v} \% \text { Glut./ } \\
\text { EDAC })\end{array}$ & 93.6 & 29 \\
\hline $\begin{array}{l}\text { Eupergit C }(1.0 \mathrm{w} / \mathrm{v} \% \text { Glut./ } \\
\text { EDAC })\end{array}$ & 90.2 & 48 \\
\hline $\begin{array}{l}\text { EDA-Amberlite XAD57 } \\
\text { (Glut. Activated) }\end{array}$ & 3.8 & 18 \\
\hline $\begin{array}{l}\text { Eupergit C ( } 0.5 \text { w/v\% Glut./ } \\
\text { EDAC) }\end{array}$ & 59.6 & 79 \\
\hline
\end{tabular}

\footnotetext{
${ }^{\text {a }}$ Binding yield is defined as the amount of protein bound on the support. This was determined by comparing protein concentrations between the initial sample and the filtrates/washings.

${ }^{\mathrm{b}}$ Activity yield is defined as the specific activity of immobilized protein as compared to the same amount of free protein. This was determined by comparing the specific activities of immobilized and free amidase.
}

Both the free amidase and immobilized preparations showed moderate thermal stability at 50 and $60^{\circ} \mathrm{C}$, respectively (Fig. 5a,b), giving extrapolated half-life $\left(t_{1 / 2}\right)$ estimates well in excess of $5 \mathrm{~h}$ at both temperatures. first-order profiles which are typical of thermal inactivation and aggregation, in that semilog plots were found to deviate from linearity (data not shown). This might suggest that alternative, possibly second-order, processes, such as proteolysis, were involved in the loss of activity. At higher temperatures, inactivation of the free enzyme was rapid, with $t_{1 / 2}$ values (calculated from semilog plots) of 43 and $10 \mathrm{~min}$ at 70 and $80^{\circ} \mathrm{C}$, respectively. In contrast, the immobilized preparations showed significant stabilization, giving calculated half-life values of 52 and $30 \mathrm{~min}$, respectively. The inactivation profiles for both enzyme preparations were linear when replotted in semilog format, indicating first-order behavior typical of thermal inactivation and aggregation processes.

\section{Substrate selectivity and chiral specificity}

The G. pallidus RAPc8 amidase was found to be highly active on short-chain aliphatic amides such as acrylamide, propionamide, and acetamide, and moderately active on substituted short-chain and mid-length aliphatic amides such as fluoroacetamide, diacetamide, lactamide and isobutyramide (Table 3 ). No activity was detectable on longchain aliphatic amide hexanoamide, on the short-chain aliphatic amides urea and L-alaninamide, or with any of the aromatic substrates tested.

Comparative assays of G. pallidus RAPc8 amidase on chiral and racemic preparations of lactamide were strongly indicative that the amidase is D-selective. Thus, in assays using D-, L- or D,L-lactamide, the amidase was found to be most active on D-lactamide (specific activity $16 \mathrm{U} / \mathrm{mg}$ ), half However, the kinetics of "inactivation" did not follow the 
Fig. 3 The effect of temperature on free (a) and immobilized (b) amidase activities

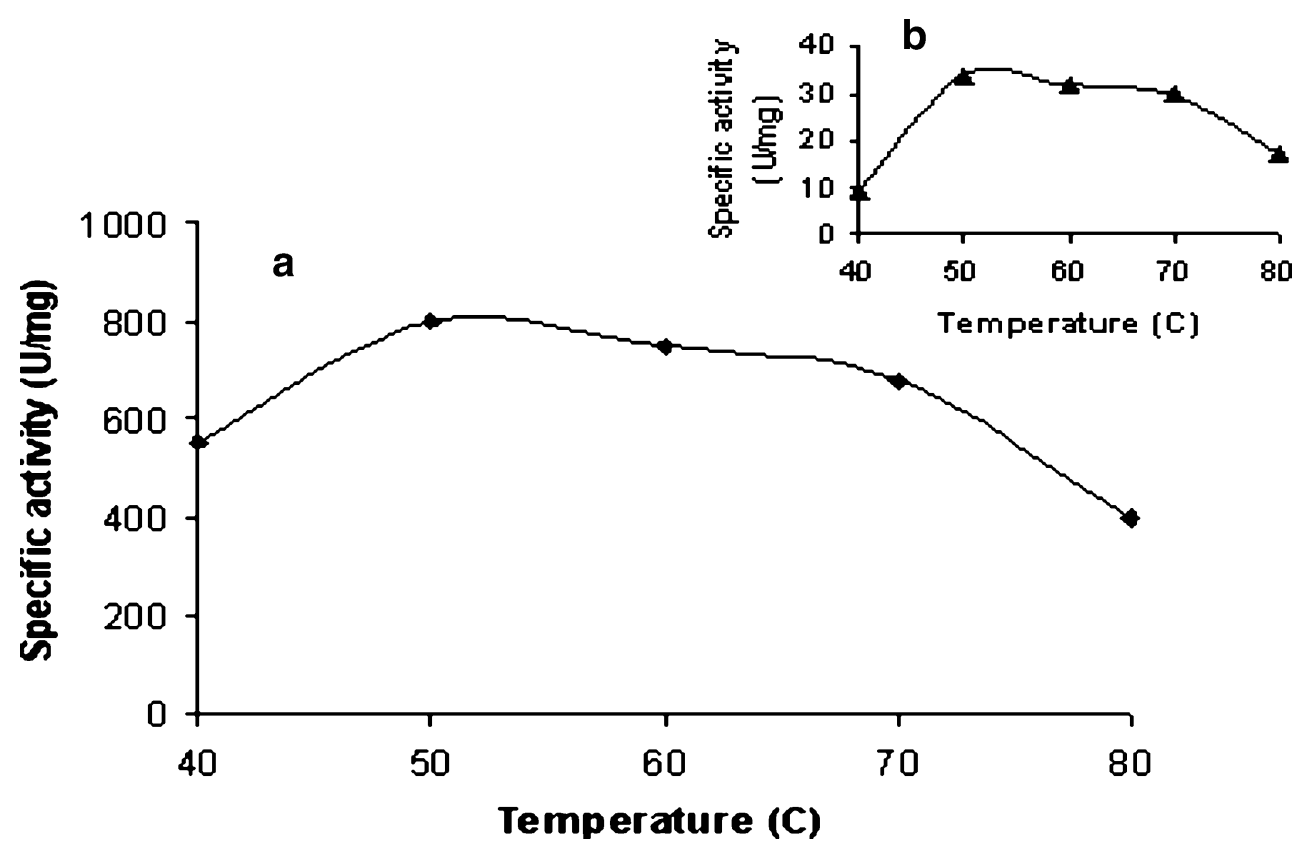

as active on D,L-lactamide (specific activity $8 \mathrm{U} / \mathrm{mg}$ ) and not active on L-lactamide. Such chiral specificity might explain the observed absence of activity on L-prolinamide. However, a reproducibly low but measurable level of activity against L-alaninamide suggests that the chiral selectivity of the amidase is not completely specific, or that in this case, the commercial D-substrate was not a pure enantiomer.

It is widely accepted that in the presence of an excess of acyl acceptor, the wide spectrum amidases (as opposed to the nitrilase superfamily amidases) can catalyze acyl transfer reactions leading to the formation of hydroxamic acids (Clarke 1970). Recently, $N$-acyltransferase activity was identified in Branch 9 members, the supernitrilase family, which react with apolipoproteins (Brenner 2002).
Significantly, acyl transferase activity has not been previously studied in a thermophilic amidase in branch 2 of the nitrilase superfamily. In this study, acyl transfer reactions catalyzed by the G. pallidus amidase were performed using various amides as substrates and hydroxylamine as a nucleophilic co-substrate. As found with hydrolysis reactions, G. pallidus amidase acyl transfer activity showed a preference for low molecular weight aliphatic amides (Table 4). The amidase was not active on long-chain aliphatic amides (hexanamide), aromatic amides (benzamide), or L-isomers of either short- and mid-length aliphatic amides (L-alaninamide and L-leucinamide). It is notable that the best substrate for acyl transfer activity was isobutyramide, although this was not the most readily hydrolyzed substrate, and the activity measured (relative to acetamide)
Fig. $4 \mathrm{pH}$-activity profiles for free (a) and immobilized (b) amidase

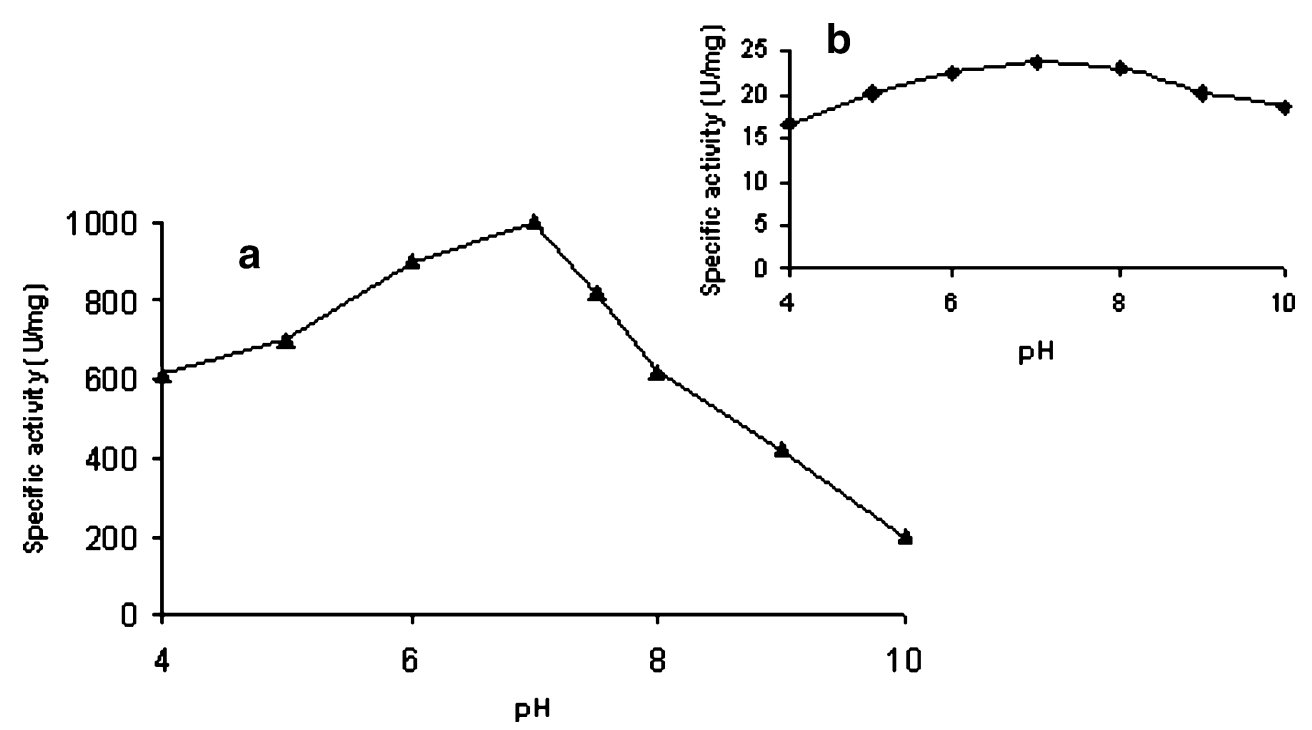




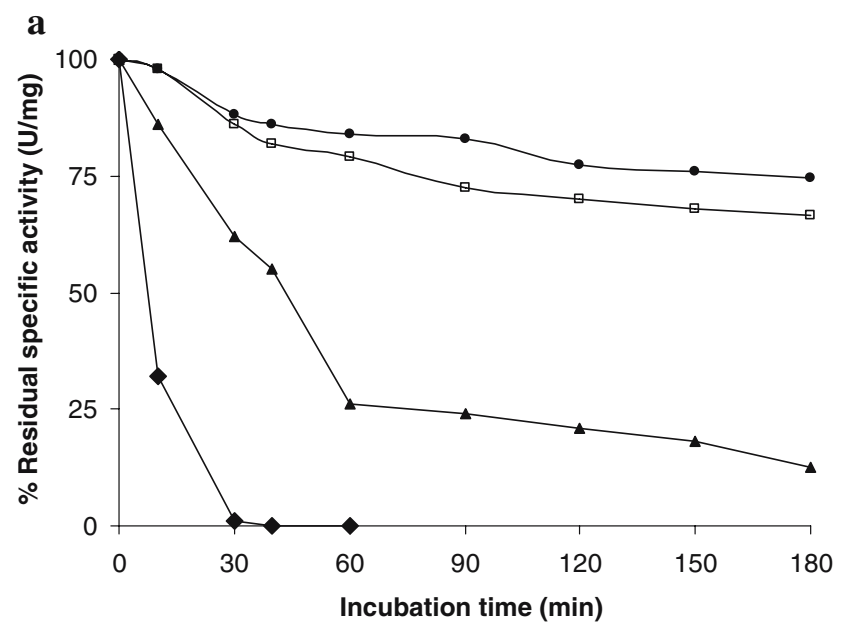

b

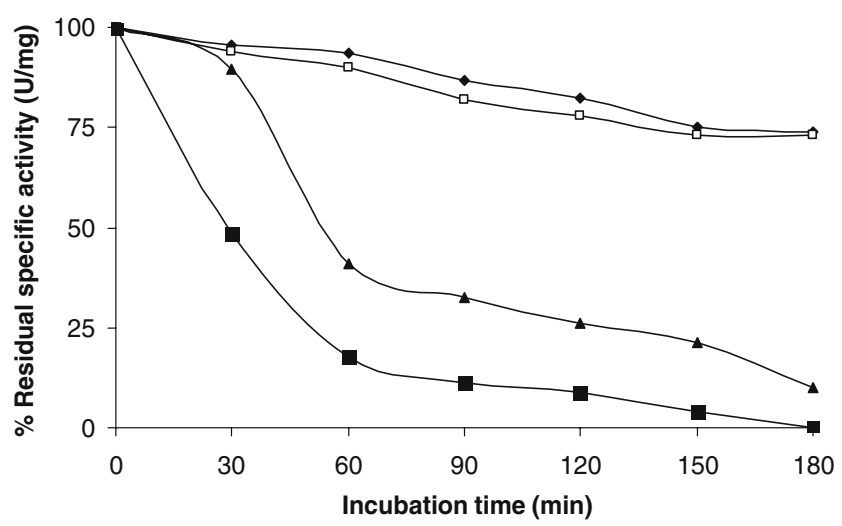

Fig. 5 Stability of free (a) and immobilized (b) amidase at $50^{\circ} \mathrm{C}$ (filled circles), $60^{\circ} \mathrm{C}$ (empty squares), $70^{\circ} \mathrm{C}$ (filled triangles) and $80^{\circ} \mathrm{C}$ (filled squares)

in this acyl transfer reaction was significantly higher than any amidase activity. This suggests a shift in chain length specificity from hydrolysis to acyl transfer.

A more detailed analysis of the amidase acyl transfer reaction kinetic parameters using two short-chain aliphatic substrates showed a very marked preference for acetamide as a substrate (Table 5). The 130-fold difference in specificity constant was dominated by the difference in $k_{\text {cat }}$, while the $K_{\mathrm{M}}$ values differed by less than a factor of 2 . Negative deviations in $v$ values at high [S] were observed (data not shown), indicating significant substrate inhibition and giving $K_{\mathrm{i}}$ values of 12.1 and $2.3 \mathrm{mM}$ for acetamide and acrylamide, respectively.

Inhibition and stability studies

Amidase activity was monitored in the presence of a range of chelating agents, redox reagents, and specific covalent and non-covalent modification reagents. The responses to these reagents were completely consistent with the presence of a catalytically active cysteine thiol group: complete inhibition was found in presence of 5\% $(v / v)$ mercaptoethanol and $\mathrm{H}_{2} \mathrm{O}_{2}$ as oxidizing agent. In the presence of $1 \mathrm{mM}$ transition metal ions $\left(\mathrm{Fe}^{3+}, \mathrm{Co}^{2+}, \mathrm{Cu}^{2+}, \mathrm{Zn}^{2+}\right)$ activity was decreased to levels between 11 and $52 \%$ of the original activity. However, activation to $150 \%$ original activity resulted form addition of the reducing agent dithiothreitol at millimole concentration. The absence of significant changes in activity in the presence of PMSF and the chelating agent ethylenediaminetetraacetic acid (EDTA) is strong evidence that neither an active site Ser residue nor coordinated metal ions (in either catalytic or stabilizing sites) are present.

We have also shown that reducing reagents stabilize the acyl transfer activity of $G$. pallidus amidase against oxidation. After incubation for 24 days at $20^{\circ} \mathrm{C}$, buffered samples of amidase without reducing agents were completely inactivated. In comparison, samples incubated in the presence of $1 \mathrm{mM}$ DTT showed activities of approximately $80 \%$ of initial levels. At $20 \mathrm{mM}$ DTT under otherwise identical conditions, acyl transfer activity was $200 \%$ higher than activities measured at time zero.

G. pallidus amidase-catalyzed reactions were also conducted in the presence of various water-miscible organic solvents present as co-solvents. Alcohols $(5 \%(\mathrm{v} / \mathrm{v})$ methanol, ethanol, $n$-butanol and isopropanol) reduced the amidase activity by $50,58,48$, and $60 \%$ respectively; acetone and acetonitrile decreased the activity of the enzyme by 86 and $93 \%$, respectively, while dimethyl sulfide (DMS) and dimethyl sulfoxide (DMSO) completely inhibited the enzyme. Amidase was quantitatively inhibited by all these co-solvents at a concentration of $10 \%(v / v)$.

\section{Discussion}

Purification of recombinant G. pallidus RAPc8 amidase by heat-treatment yielded a product of between 50 and $70 \%$ homogeneity, with fourfold purification. In addition, the heating step increased the total yield (U) of the enzyme by about $200 \%$ (Table 1). It was previously established that approximately $30 \%$ of the expressed protein was soluble (Cameron et al. 2005), and thus, this heat treatment presents a suitable method for removing insoluble aggregates. Moreover, this heat treatment effectively denatures mesophilic enzymes including proteases, which may otherwise negatively affect the biocatalyst. For many applications, and particularly for biocatalytic processes, this simple one-step purification process would be adequate and economically efficient. However, purification to greater than $90 \%$ homogeneity was achieved by addition of a limited number of additional chromatography steps (Agarkar et al. 2006). An increase in total activity during purification of thiol-dependent enzymes is commonly observed, and is generally 
Table 3 Amidase activities with different amide substrates

\begin{tabular}{|c|c|c|c|}
\hline SUBSTRATE & $\begin{array}{c}\text { RELATIVE } \\
\text { ACTIVITY }(\%) \\
\end{array}$ & SUBSTRATE & $\begin{array}{c}\text { RELATIVE } \\
\text { ACTIVITY }(\%)\end{array}$ \\
\hline Nicotinamide & 0 & L-Alaninamide & $\mathrm{NH}_{2}$ \\
\hline Isonicotinamide & 0 & Diacetamide & 14 \\
\hline Benzamide & 0 & Isobutyramide & 16 \\
\hline L-Asparagine & 0 & Lactamide & 17 \\
\hline D-Asparagine & 0 & Formamide & 30 \\
\hline DL-Phenylalanine & 0 & Flouroacetamide & 165 \\
\hline L-Prolinamide & 0 & Propionamide & 67 \\
\hline Urea & 1.5 & Acetamide & 100 \\
\hline Hexanamide & 0 & Acrylamide & 102 \\
\hline
\end{tabular}

$* 100 \%$ activity $=148 \mathrm{U} / \mathrm{mg}$ specific activity under standard reaction conditions using $25 \mathrm{mM}$ acetamide 
Table 4 Acyl transfer activity of G. pallidus RAPc8 amidase

\begin{tabular}{llc}
\hline \multicolumn{2}{c}{ SUBSTRATE } & $\begin{array}{c}\text { RELATIVE } \\
\text { ACTIVITY* }\end{array}$ \\
\hline Acetamide & 100 \\
\hline Lactamide & & \\
\hline Isobutyramide & & \\
\hline 100\% activity $=1180 \mathrm{U} / \mathrm{mg}$ specific activity using acetamide
\end{tabular}

attributed to removal of reversibly inactivating contaminants (particularly heavy metal ions). The active enzyme comprised a homohexamer with a dimension of $10 \mathrm{~nm}$ having D3 symmetry. A separable subpopulation of hexamers formed linear aggregates under the solution conditions utilized.

Alignments of the primary sequence of the G. pallidus RAPc8 amidase suggested that the catalysis depends on a Glu, Lys, Cys catalytic triad, typical of the nitrilase superfamily (Cameron 2002; Cameron et al. 2005). Inhibition by heavy metal ions such as $\mathrm{Hg}^{2+}, \mathrm{Fe}^{2+}$, and $\mathrm{Co}^{2+}$ is consistent with this suggestion (Table 4). The presence of DTT in the reaction mixture resulted in an approximately 1.5-fold increase in amidase activity (Table 4), which suggests the important role of sulfhydryl groups in the mechanism of action of the enzyme.

Studies of the substrate specificity of the amidase have shown that the amidase from G. pallidus RAPc8 is not capable of hydrolyzing aromatic amides or long-chain aliphatic amides. In common with many wide-spectrum amidases (Fournand and Arnaud 2001), acetamide, acrylamide, and propionamide were the most rapidly hydrolyzed amides. The G. pallidus sp. RAPc8 amidase also exhibited chiral specificity towards the pure isomers and a racemic mixture of lactamide.
The different immobilization techniques used to stabilize the $G$. pallidus RAPc8 amidase showed that both low-protein binding yield and recovered amidase activity were highly sensitive to the method selected (Table 2). It was noted that covalent attachment of the amidase on Eupergit $\mathrm{C}$ beads at $25^{\circ} \mathrm{C}$ resulted in low protein-binding yields but retention of high amidase activity. Modification of this immobilization technique by subsequent cross-linking with glutaraldehyde and EDAC significantly improved the protein-binding yield, although high concentrations of the cross-linking agents inhibited amidase activity. The half-lives of the free and immobilized amidase at $70^{\circ} \mathrm{C}$ were found to be approximately 20 and $50 \mathrm{~min}$, respectively. At $80^{\circ} \mathrm{C}$, the half-life of the immobilized amidase was increased by a factor of approximately 2. Enzyme immobilization has often been reported to improve the stability of enzymes and may affect other functional properties. We have demonstrated that the optimum reaction temperature of the amidase remained unchanged after immobilization, while its activity at high $\mathrm{pH}$ was enhanced. It is also interesting to note that despite the presence of lysine in the active site, glutaraldehyde cross-linking was found to be useful. This suggests that the active site must be well-protected from external reactions.

Generally, amide-converting enzymes are known to be active over a narrow range of temperatures and $\mathrm{pH}$ values (neutral or slightly alkaline), to require heavy metal-free conditions and to tolerate only low percentages of cosolvents (Mylerova and Martinkova 2003). While the primary characterization of this amidase has shown similar results, the operational temperature of the enzyme is considerably higher than most mesophilic enzymes. The optimal operating conditions of the amidase (in terms of reaction temperature and $\mathrm{pH}$ ) were found to be largely unchanged after immobilization, but the immobilized amidase was found to have significantly improved thermal stability and a broader $\mathrm{pH}$ range of activity. This would be an advantage in industrial applications.

Based on the substrate and chiral selectivity data reported here, G. pallidus RAPc8 amidase could be utilized as a biocatalyst for the hydrolysis of low molecular weight aliphatic amides to yield optically pure D-carboxylic acids and for synthesis of novel amides via the acyl transfer

Table 5 Kinetic parameters for G. pallidus RAPc8 amidase acyl transfer reaction

\begin{tabular}{|c|c|c|c|c|c|}
\hline Substrate & $K_{\mathrm{M}}(\mathrm{mM})$ & $V_{\max }\left(\mathrm{nmol} \min ^{-1}\right)$ & $k_{\text {cat }}\left(\mathrm{s}^{-1}\right)$ & $k_{\text {cat }} / K_{\mathrm{M}}\left(\mathrm{mM}^{-1} \mathrm{~s}^{-1}\right)$ & Specific activity $\left(\mathrm{U} \mathrm{mg}^{-1}\right)$ \\
\hline Acetamide & 22.7 & 114 & 2,668 & 117 & 4,140 \\
\hline Acrylamide & 43.8 & 66.2 & 38.7 & 0.88 & 60.2 \\
\hline
\end{tabular}

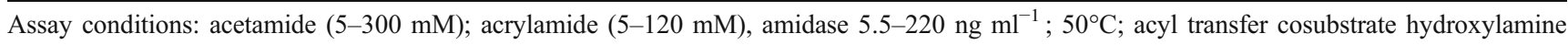
$(0.5 \mathrm{mM})$ 
reaction. Furthermore, as the amidase retained significant activity in the presence of certain organic solvents, reaction engineering approaches could be used to extend the utility of the enzyme as an industrial biocatalyst. An investigation of this aspect is underway in our laboratory.

We conclude that the G. pallidus RAPc8 amidase is a novel thermostable nitrilase superfamily amidase which has potential for application, under moderate-to-high temperature conditions, as a biocatalyst not only for D-selective amide hydrolysis to produce enantiomerically pure carboxylic acids but also for production of novel amides.

\section{References}

Agarkar VB, Kimani SW, Cowan DA, Sayed MF-R, Sewell BT (2006) The quaternary structure of the amidase from Geobacillus pallidus RAPc8 is revealed by its crystal packing. Acta Crystallogr F62:1174-1178

Banerjee A, Sharma R, Banerjee UC (2002) The nitrile-degrading enzymes: current status and future prospects. Appl Microbiol Biotechnol 60:33-44

Brenner C (2002) Catalysis in the nitrilase superfamily. Curr Opin Struct Biol 12:775-782

Bretaudiere JP, Frank J (1986) Reconstitution of molecule images analysed by correspondence analysis: a tool for structural interpretation. J Microsc 1986:44

Cameron RA (2002) Nitrile degrading enzymes from extreme environments. PhD thesis, University College, London

Cameron RA, Sayed M, Cowan DA (2005) Molecular analysis of the nitrile catabolism operon of the thermophile Geoacillus pallidus RAPc8B. Biochim Biophys Acta 1725:35-46

Chebrou H, Bigey F, Arnaud A, Galzy P (1996) Study of the amidase signature group. Biochim Biophys Acta 1298:285-293

Clarke PH (1970) The aliphatic amidases of Pseudomonas aeruginosa. Adv Microb Physiol 4:179-222

Crowther RA, Henderson R, Smith JM (1996) MRC image processing programs. J Struct Biol 116:9-16

Farnaud S, Tata R, Sohi MK, Wan T, Brown PR, Sutton BJ (1999) Evidence that cysteine-166 is the active-site nucleophile of Pseudomonas aeruginosa amidase: crystallization and preliminary X-ray diffraction analysis of the enzyme. Biochem J 340:711-714

Fournand D, Arnaud A (2001) Aliphatic and enantioselective amidases: from hydrolysis to acyl transfer activity. J Appl Microbiol 91:381-393

Fournand D, Pirat J-L, Bigey F, Arnaud A, Galazy P (1997) Spectrophotometric assay of aliphatic monohydroxamic acids and $\alpha-, \beta-$, and $\gamma$-aminohydroxamic acids in aqueous medium, Analy Chim 353:359-366
Fournand D, Bigey F, Aranaud A (1998) Acyl transfer activity of an amidase from Rhodoccus sp. R312: Formation of a wide range of hydroxamic acids. Appl Environ Microbiol 64:2844 2852

Frank J (2006) Three-dimensional electron microscopy of macromolecular assemblies: visualization of biological molecules in their native state. Oxford University Press, New York

Frank J, Radermacher M, Penczek P, Zhu J, Li Y, Ladjadj M, Leith A (1996) SPIDER and WEB: processing and visualization of images in 3D electron microscopy and related fields. J Struct Biol 116:190-199

Kobayashi M, Fujiwana Y, Goda M, Komeda H, Shimizu S (1997) Identification of active sites in amindase: evolutionary relationship between amide-bond and peptide bond-cleaving enzymes. Proc Natl Acad Sci USA 94:11986-11991

Kotlova EK, Chestukhina GG, Astaurova OB, Leonova TE, Yanenko AS, Debabov VG (1999) Isolation and primary characterization of an amidase from Rhodococcus rhodochrous M8. Biochemistry 64:384-389

Laemmli UK (1970) Cleavage of structural proteins during the assembly of the head of bacteriophage T4. Nature 227:680 685

Madhavan NK, Roopesh K, Chacko S, Pandey A (2005) Comperative study of amidase production by free and immobilised Escherichia coli cells. Appl Biochem Biotechnol 120:97-108

Mylerova V, Martinkova L (2003) Synthetic applications of nitrileconverting enzymes. Curr Org Chem 7:1-17

Nakai T, Hasegawa T, Yamashita E, Yamamoto M, Kumasaka T, Ueki T, Nanba H, Ikenaka Y, Takahashi S, Sato M et al (2000) Crystal stucture of N-carbamyl-D-amino acid amidohydrolase with a novel catalytic framework common to amidohydrolases. Structure 8:729-737

Pace HC, Brenner C (2001) The nitrilase superfamily: classification, structure and function. Gen Bio 2:1-9

Pace HC, Hodawadekar SC, Draganescu A, Huang J, Bieganowski P, Pekarsky Y, Croce CM, Brenner C (2000) Crystal structure of the worm NitFhit Rosetta stone protein reveals a Nit tetramer binding two Fhit dimers. Curr Biol 10:907-917

Pereira RA, Graham D, Rainey FA, Cowan DA (1998) A novel thermostable nitrile hydratase. Extremophiles 2:347-357

Toogood HS, Taylor IN, Brown RC, Taylor SJC, Mccageu R, Littlechild JA (2002) Immobilization of the thermostable Laminoacylase from Thermococcus litoralis to generate a reusable industrial biocatalyst. Biocatal Biotrans 20:241-249

Torres-Bacete J, Arroyo M, Torres-Guzman R, de la Mata I, Castallon MP, Acebal C (2000) Covalent immobilization of penicillin acylase from Streptomyces lavendulae. Biotechnol Appl Biochem 32:173-177

Torres-Bacete J, Arroyo M, Torres-Guzman R, de la Mata I, Castillon MP, Acebal C (2001) Stabilization of penicillin V acylase from Streptomyces lavendulae by covalent immobilization. J Chem Technol Biotechnol 76:525-528

Weatherburn MW (1967) Phenol-hypochlorite reaction for determination of ammonia. Anal Chem 39:971-974 